\title{
Indigenous knowledge on development and management of shallow dug wells of Dodoma Municipality in Tanzania
}

\author{
C. Shemsanga ${ }^{1,3} \cdot$ A. N. N. Muzuka ${ }^{2} \cdot$ L. Martz ${ }^{2}$ H. Komakech ${ }^{1} \cdot$ E. Mcharo $^{4}$
}

Received: 26 June 2015 / Accepted: 18 October 2017 / Published online: 19 April 2018

(c) The Author(s) 2018

\begin{abstract}
Dodoma city, central Tanzania, seats in a semi-arid region of East Africa with limited rains and surface water resources. Consequently, the area largely depends on shallow and deep aquifers for its freshwater needs. Owing to harsh climatic conditions, chronic lack of year-round surface water bodies and, limited development of water distribution infrastructures, over year's local people have nurtured, developed and, passed on important indigenous knowledge (IK) on exploiting and managing shallow aquifers (SAs). However, there is no clear documented administrative plans for the SAs and the roles of IK, which is widely practised in developing SDWs and managing SAs, are not properly documented. This study intended to assess the extent of shallow dug wells (SDWs) utilization and contribution of IK on management of SAs of indigenous people of Dodoma Municipality. The methods followed include critical field observations, measurements and, focus group discussions done during both the dry season (Sep.-Oct. 2013) and wet season (Dec. 2013-Feb. 2014). The results show that SDWs occur widely in the city, particularly in the suburbs, where they often serve as the only sources of freshwater and heavily dependent by the populace. It is clear that there is rich IK on management of SAs including on groundwater exploration, digging, water allocation, pricing, and even on water quality and, water treatment skills. The aforementioned IK clearly contribute to water sufficiency to the populace and general management of groundwater such as enhancing recharge mechanisms where about $1 \%$ of local rainfall is recharged through a network of SDWs compared to $5-10 \%$ that is naturally being recharged by rainfall through the vadose zone. Thus, as much as the current policy framework and groundwater managers do not recognize the roles of IK and contributions of SDWs as key water sources, it is clear that IK contributes to the groundwater management and SDWs already support large part of the society. While it is globally appreciated that vital skills on SDWs management are vanishing, local people in Dodoma still retain them and should, therefore, be preserved. It is further recommended that IK are strengthened, improved and most importantly, incorporated in the local water resources management plans that already advocate on integrated approaches but which clearly ignores the IK and the local people's efforts to explore and manage water resource, particularly SAs.
\end{abstract}

Keywords Shallow aquifers $\cdot$ Indigenous knowledge $\cdot$ Management $\cdot$ Dodoma

C. Shemsanga

7ceven@gmail.com

1 Department of Water and Environmental Sciences and Engineering, Nelson Mandela African Institution of Science and Technology, Arusha, Tanzania

2 Department of Geography and Planning, University of Saskatchewan, Saskatoon, Canada

3 Department of Environmental Engineering and Management, School of Environmental Sciences and Technology, University of Dodoma, Dodoma, Tanzania

4 Water Resources Division, Ministry of Water, Dodoma, Tanzania

\section{Background information}

\section{Introduction}

Owing to the lack of year-round surface water bodies, low rains, and poor quality of the available surface water bodies, in Dodoma city, reliability of fresh water supplies for various uses has largely been met by groundwater (Salama 1979; Rwebugisa 2008). In recent years, however, per capita freshwater availability has further been reduced by population increases and ongoing impacts of climate change (Kashaigili 2010; Rwebugisa 2008). Yet, the negative climate change impacts on surface water resources and increasing pressure 
on groundwater for agriculture, construction and, domestic use will likely exacerbate the problem of freshwater supply further (Shemsanga et al. 2016).

Generally, groundwater is considered less sensitive to short-term climate variability and even pollution sources (Chen et al. 2004). According to Wurzel (2001), groundwater is protected from evaporation and, in many regions; volumes stored underground are immense, providing water security during drought periods/years. Yet, the capital cost of groundwater development is also relatively low. Thus, the afforested traits qualify groundwater as a major adaptation option to the negative impacts of climate change on water supplies (Chen et al. 2004). Local people in Dodoma city have capitalized on these key groundwater traits from which they have survived ages of chronic water shortages via inherent indigenous knowledge (IK) associated with shallow aquifers (SAs) exploration, development and management.

However, groundwater dynamics in Dodoma are not fully understood which undermines efforts for sustainable management of local and regional aquifers. Yet, management of groundwater is generally complex as is viewed and as such, treated as a common pool resource (Troch 2000; Zealand 2011), including within the study area (Kashaigili 2010). Poor understanding of groundwater is even more serious with shallow aquifers that are currently not of interest to local researchers, policy makers and, water resource managers (personal communication with Mr. Mihale, WamiRuvu Basin, WRB). This remains the case when as much as $20-30 \%$ of Dodoma region is regarded suitable for shallow dug wells (SDWs) development (Baumann et al. 2005) and where SDWs occur widely in the region. Likewise, local SDWs are not properly documented making it difficult to estimate their contributions in the local water sufficiency and balance as is the case for the role of IK associated with their development and utilization. However, deep aquifers particularly at Makutupora well field (MWF), the main source of water supply of the city, remains strongly interlinked with shallow aquifers (Shindo 1990) hence poor management of local SDWs may affect deep wells alike. A SDW in this context mean a well that is $\leq 15 \mathrm{~m}$ deep (De Louw et al. 2013). These, are often easy to dig and the wells themselves act as own reservoirs hence making storage tanks unneeded (Taylor et al. 2009; Job 2010) and in many areas there are local skills to develop and manage them (Wurzel 2001; Pritchard et al. 2008; Hardjoamidjojo et al 2007).

The national water management plan advocates on holistic approaches such as integrated water resource management (IWRM), creation of water user associations and, issuing of water development and use permits. However, local water management is often marred by conflicting interests and issuing of the permits and paying of needed fees is nationally unrealistic due to the presence of numerous unknown abstractions and incapacity to implement existing guidelines and collection of the fees (Baumann et al. 2005). This remains the case while locals have plenty of skills on many of these aforelisted challenges, yet the current water management strategy does not recognize/include them.

Moreover, over generations harsh climatic conditions coupled with poor water quality and/or lack of surface water bodies and chronic water shortage have led to nurturing and passing on of vital IK on development and general management of SDWs. For meaningful and sustainable groundwater management, therefore, there is a need to integrate these rich IK on management of the local water resources' governance. However, no proper documentation of IK exists locally and little is known on its roles in management of water resources. Nonetheless, water management must focus on total water resource; surface and underground, in various states and places, and the people who live with, impact, use and, manage it. This should consider everybody and every process that affects its quality and quantity or that is affected by various water projects. Specifically, it must include IK as local people have enormous skills from older generations that have enabled them to survive ages of water stress.

However, it should be known that water shortage is a problem in the wider developing world particularly in semiarid regions where more than 1.1 billion people do not have reliable access to water for drinking (Nkonya 2011). Meeting regional water needs will thus depend on how water resources are understood, developed and most importantly, managed (MacDonald et al. 2009, 2010). By 2005, it was reported that to meet Millennium Development Goals (MDG) on water, Tanzania needed to drill 14000 SDWs and 1500 boreholes per year (Baumann et al. 2005). For such a task to be sustainable, an understanding of available water resources, functional allocation systems and cautious balancing of surface and groundwater abstractions are required (Taylor et al. 2012; Shemsanga et al. 2017). Many of these aforelisted aspects are already practised by the local people in Dodoma city but lack proper documentation, coordination and policing.

Groundwater exploration is usually carried out using lengthy and expensive methods namely geospatial techniques (Hammouri et al. 2012; Manap et al. 2014) and geophysical techniques (Muchingami et al. 2012), among many others. For a long time, however, local people in Dodoma city have successfully explored for groundwater using traditional and locally available means and tools. These, however, are also not well documented, coordinated and, recognised by existing water development and management framework which undermines local efforts for water sufficiency to all.

Classifying water quality is vital for overall water management and allocation plans (Mjemah et al. 2009, 2011). Conventionally, water quality assessment is often done by lengthy and costly process of laboratory analysis of a series of water quality parameters. However, locals have developed 
simple means of water quality assessment including identification of catchment areas with saline and hard groundwater. Besides, IK on allocating groundwater for different uses based on qualitative parameters exists but not properly documented and formally recognised. Yet, these skills have enabled local people to designate water sources according to their quality and it can only be meaningful if such efforts will be studied, improved and, if necessary included in the ongoing water management efforts.

Despite the high rate of SDWs development and utilization and the rich indigenous knowledge base on SGs management in Dodoma Municipality, these remain undocumented and effectively excluded in the formal water governance strategies and framework. This remains the case long after the UN recognized robust roles of IK as its 3rd priority in the Hyogo Framework for Action (ISDR 2012). Thus, this study intended to assess contributions of the local people in Dodoma Municipality and how the entire
IK structure on management of SAs works. The study also aimed at providing initial quantification of SDWs density and the corresponding recharge fluxes in Dodoma Municipality. It is hoped that the local IK perspectives coupled with on-going scientific effort to manage water resources will lead to better understanding, henceforth management of surface and groundwater resources.

\section{Case study description}

This study was carried out within the Dodoma municipality that is located between UTM zone 36 , UTM $750,000 \mathrm{E}$ through 945,000 E and 9,280,000 N through 9,380,000 N (UTM, Arc 1960) (Fig. 1). Meteorologically, the area is in a semi-arid region of Tanzania with low $(550 \mathrm{~mm} /$ year) unimodal rains falling between October and May. Temperatures are lowest in July (about $13.0^{\circ} \mathrm{C}$ ) and highest in November (about $30.6{ }^{\circ} \mathrm{C}$ ). The semi-aridity nature of the area can be

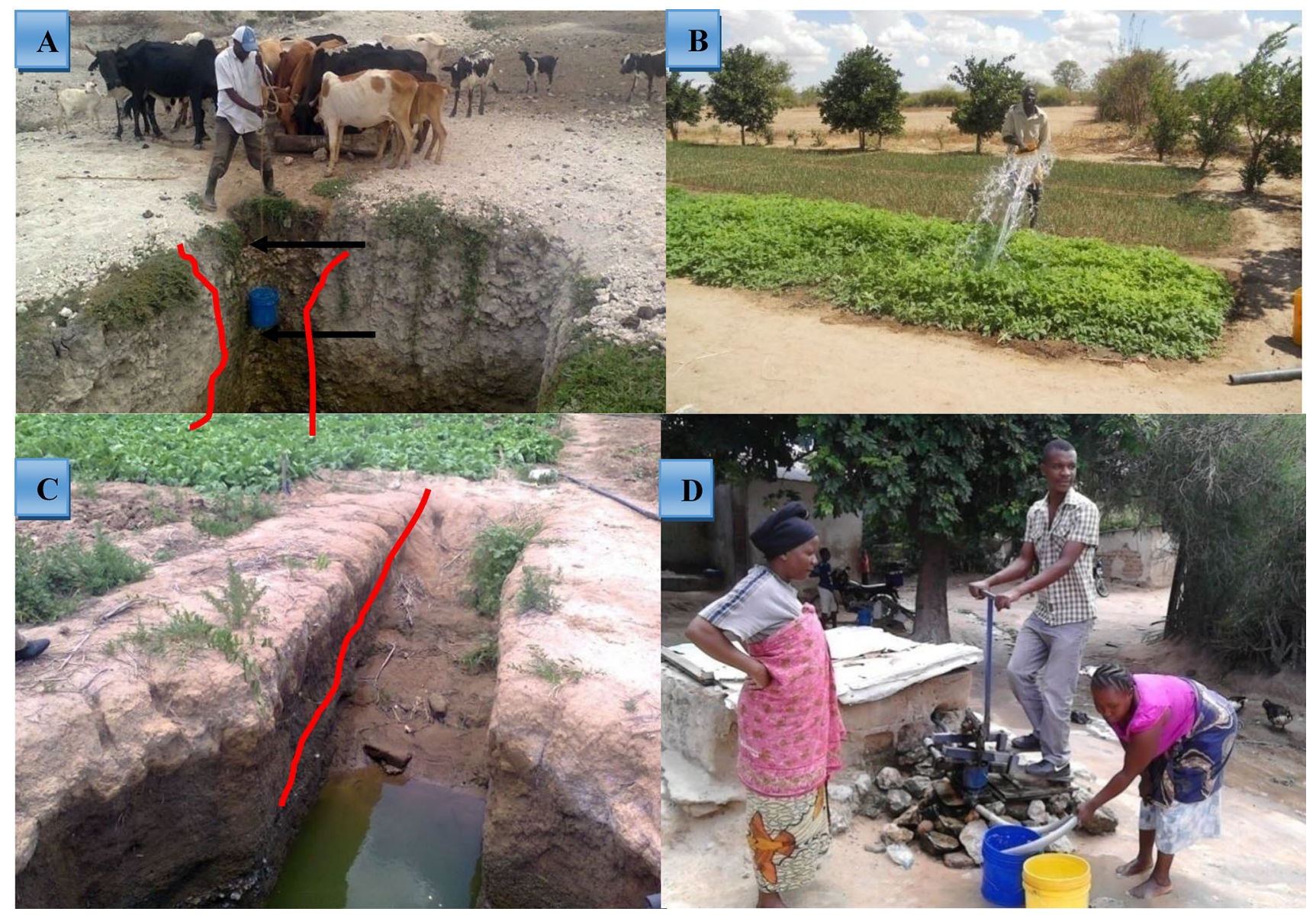

Fig. 1 Major SDWs uses, designs, types of water abstractions in Dodoma Municipality. a A pastoralist abstracting water for his livestock, and lack of proper SDWs completion practices making them susceptible to surface runoff which can easily contaminate the wells b shows a farmer irrigating a garden at Nzuguni using his own SDWs. a, c, d shows various types of traditional SDWs and pumping sys- tems used for water abstraction. a Shows the traditional bucket and rope water abstraction system that has the potential to contaminate the aquifer. d Wells' completion and water pumping system where a SDWs is fixed with a peddle pump and carefully protected by locally available materials which reduces chances of aquifers' contamination 
appreciated from very high evapotranspiration (ET) rates averaging at $2000 \mathrm{~mm} /$ year (Rwebugisa 2008), this rate is about 4 times the annual rainfall (Shindo 1991). Hydrologically, the area is notable for a series of seasonal rivers and lack of permanent surface water bodies, except for the saline Hombolo Dam (Fig. 1; Shemsanga et al. 2017). The local river network is largely seasonal, flowing only during the rainy season and a few weeks thereafter hence the area is heavily reliant on groundwater. Geologically, it lies in the fractured and sheared, crystalline basement of Dodoma craton composed of granite, granulites and, migmatite intruded by dolerite/diorite and pegmatite dykes. There is also a narrow belt of metasedimentary rocks (Hombolo-Meia Meia) composed of ferruginous quartzites, ironstones, micaceous quartzites, quartz feldspathic schists (Shindo 1991; Nkotagu 1996a). The area has a moderate population growth rate (3.3\%) and it is projected that by 2025 the total population will be 689,072 compared to 324,437 in 2002 (URT 2003). Projections show that by $2025,94,218 \mathrm{~m}^{3} /$ day of water will be required compared to about $38,006 \mathrm{~m}^{3} /$ day of 2002 (URT 2003) which represents a real challenge.

\section{Methods}

This study was triggered by a high level of IK on various aspects of management of SAs and development and utilization of SDWs that were observed within the study area. The methods followed include analysis of climate data, focus group discussions (FGDs), extended FOs of SAs management strategies and measurements on SDWs design dimensions and yield. Physical water quality parameters were measured in situ using a field multi-parameters testing kit (portable Scichem STC multi-parameters tester). Focus group discussions with the local people were held around SDWs as/when they were going about their daily activities viz fetching water, gardening and, trailing livestock to drink water from the wells. This gave an unbiased opportunity to observe how the entire system of local groundwater development and management works. Despite immense skills on the management of SDWs, several skilful people in management of SDWs namely the elders and traditional leaders; could not communicate in Swahili and/or English but local Gogo language. When the use of Gogo was necessary, the field technician (Mr. Malima) provided translations. Focus group discussions and FOs were done for the period of five (5) months covering both dry (Sep-Oct 2013) and wet seasons (Dec 2013-Feb 2014). The various accounts and findings uncovered in the field were discussed with officials charged with management of water resources at WRB, Dodoma office.

Meteorological data of rainfall and temperature were collected from Makutupora (1921-2014), Dodoma (1980-2014) and Hombolo agro-vet (1980-2014) meteorological stations.
In all areas, wells' owners, village leaders and elders helped the research team to identify SDWs in their localities and designated their uses, management strategies and whether they were perennial or ephemeral. Although the SDWs were dug with the purpose of providing water, it was clear that they also work as potential recharge avenues to the SAs which was calculated from the following two methods;

(a) Recharge based on vertical flux from precipitation on existing SDWs' surface areas

Recharge from a single SDW $=$ SDW exposed area

$$
\times \text { average annual rainfall. }
$$

(b) Recharge from rainfall and water infiltrating into the SDWS due to changes in pressure created by opening of the SDWs according to Sunderrajan et al. (2009).

Recharge per Unit area $=$ Recharge from a single SWD

$$
\times \text { SDWs denisty. }
$$

SDW density $=$ Number of SDWs $/$ total area

Average SDW volume (recharge volume from a single well)

$$
=\frac{\pi D^{2}}{4} \times d \text {. }
$$

\section{Major assumption}

All SDWs are full once a year from precipitation and water infiltrating into the SDWs due to changes in pressure created by the vacuum caused by opening up of the wells and that the entire volumes of the wells will recharge the shallow aquifers. Due to data availability constraints, only Mtumba and Ihumwa suburbs were chosen in the estimation magnitudes of recharge contribution from SDWS. Where $D=$ average SDWs diameter, $d=$ average SDWs depth. This study was guided by the following research questions from which FGDs, field work and, data collection were planned;

(a) How do the local people in Dodoma explore for the best sites/locations to dig SDWs?

(b) How are the SDWs developed by the local people in Dodoma?

(c) How are SDWs and surrounding recharge areas (catchment) managed?

(d) How is the water allocated and shared amongst different sectors, users and, uses?

(e) What proportion of the local people are directly dependent on the SDWs?

(f) What is the local knowledge base on water quality issues and water treatment methods?

(g) How do the SDWs development contribute to water management like enhancing recharge? 


\section{Results}

\section{Shallow dug wells' density and uses}

Table 1, summarises the number of local SDWs and whether they are perennial or ephemeral. The results show that there were over 1248 SDWs of both rectangular and round types (Table 1, Fig. 1). Proportionally, 35, 19, 38 and, 8\% of all wells were used for irrigation, domestic, mixed uses and livestock, respectively. In addition, most wells (93\%) are privately owned while $7 \%$ were communal wells. The SDWs are more common in the suburbs and un-surveyedlow income areas (Table 1). For instance, 336 wells occur in Mtumba which is one of heavily populated area with no piped water connections. Within the suburbs, nearly $76 \%$ of the population totally depend on SDWs compared to only $8 \%$ of the urban population (Table 1). Furthermore, occurrence of SDWs within the municipality is mostly in un-surveyed urban settlements of Nkuhungu, Nzuguni, Ntyuka, Ndachi, Mbwanga and, Mbuyuni where no water infrastructures and connections exist. Generally, within the suburbs, dominance of SDWs numbers follow the following order Hombolo Makulu, Mahoma Nyika, Mtumba, Ihumwa, Nzuguni and, Vyeyula, respectively. Notice the proportionally large number of SDWs density in the suburbs $(96.71 \%)$ compared to the city centre (3.29\%) (Table 1).
Estimation of recharge from shallow dug wells (SDWs)

\section{Method 1}

Direct recharge from vertical precipitation flux on SDWS surfaces

Recharge from all SDWs surfaces $=2.5 \times 3 \times$ $579 / 1000=4.3425 \mathrm{~m}^{3}$. Considering all study SDWs (1248), this gives a total of $5,419.44 \mathrm{~m}^{3}$.

\section{Method 2}

Recharge from vertical precipitation flux on SDW surfaces and water infiltrating into the SDWs according to Sunderrajan et al. (2009). Working with average SDWs dimensions and applying Eqs. (1-3), net recharge per unit areas was estimate as portrayed hereunder (Fig. 2).

By applying the following values into Eqs. (2) through (4), recharge amounts were calculated as follows,

$D=$ Average diameter of SDWs $(2.5 \mathrm{~m})$

$d=$ Average depth of SDWs $(15 \mathrm{~m})$

Area (Mtumba and Ihumwa) $=8,000,000 \mathrm{~m}^{2}$

Number of SDWs $=548, \Pi=3.1416$

SDWs density $=6.85 \times 10^{-5}$ wells $/ \mathrm{m}^{2}$

Average SDWs recharge volume $=73.66 \mathrm{~m}^{3}$

Recharge per unit area $=5.04571 \times 10^{-3} \mathrm{~m}(5.046 \mathrm{~mm})$.

Recharge from a single $\mathrm{SDW}=2.5 \times 579 / 1000$ $(=1.4475)$

Total recharge from all SDWs

$=1.4475 \mathrm{~m}^{2} \times 1248=1806.48 \mathrm{~m}$
Table 1 SDWs distribution and characteristics based on FOs, FGDs and, URT $(2013,2014)$

\begin{tabular}{|c|c|c|c|c|c|c|}
\hline Sub-catchment & Status & Town planning status & No. of wells & No. of people & Perennial wells & $\begin{array}{l}\text { Ephem- } \\
\text { eral wells }\end{array}$ \\
\hline Hombolo & Mixed & Un-surveyed & 73 & 16,147 & 58 & 15 \\
\hline Hombolo Makulu & Rural & Mostly un-surveyed & 34 & 6309 & 28 & 6 \\
\hline Makutupora & Mixed & Mostly un-surveyed & 12 & 14,430 & 5 & 7 \\
\hline Iyumbu & Rural & Un-surveyed & 31 & 5567 & 29 & 2 \\
\hline Nala & Mixed & Un-surveyed & 13 & 5567 & 9 & 4 \\
\hline Zuzu & Rural & Un-surveyed & 25 & 6485 & 19 & 6 \\
\hline Miyuji & Mixed & Mostly un-surveyed & 8 & 14,965 & 8 & 0 \\
\hline Mkonze & Rural & Un-surveyed & 11 & 12,515 & 8 & 3 \\
\hline Msalato & Mixed & Mostly un-surveyed & 14 & 6718 & 11 & 3 \\
\hline Ntyuka & Mixed & Mostly un-surveyed & 39 & 4558 & 33 & 6 \\
\hline Dodoma urban & Urban & Mostly Surveyed & 41 & 44,050 & 27 & 14 \\
\hline Ihumwa & Mixed & Mostly un-surveyed & 212 & 10,577 & 187 & 25 \\
\hline Mtumba & Mixed & Mostly un-surveyed & 336 & 6691 & 298 & 38 \\
\hline Mahoma Nyika & Rural & Un-surveyed & 64 & 3023 & 23 & 41 \\
\hline Mahoma Makulu & Rural & Un-surveyed & 263 & 4365 & 176 & 87 \\
\hline Nzuguni & Mixed & Mostly un-surveyed & 72 & 15,466 & 59 & 13 \\
\hline Total & & & 1248 & 177,433 & 978 & 270 \\
\hline
\end{tabular}




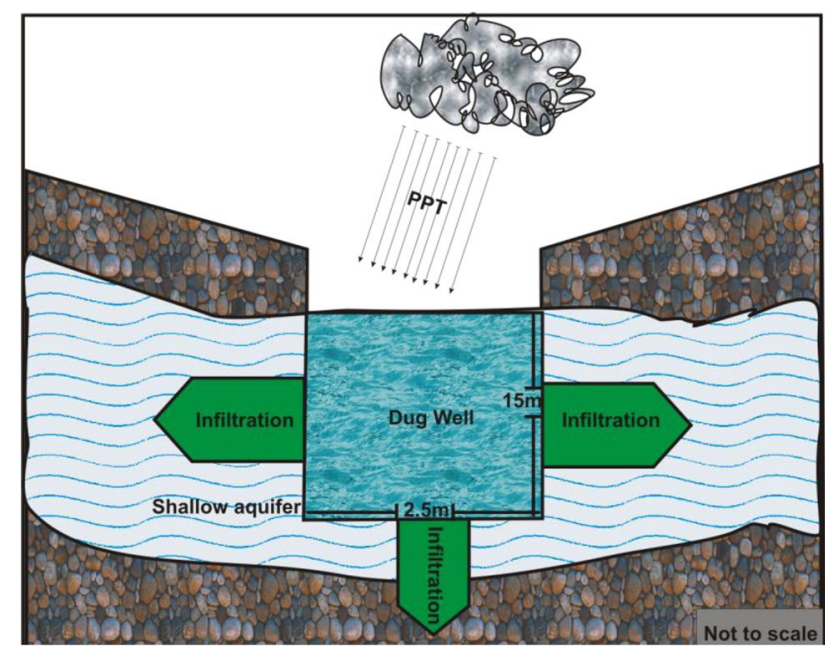

Fig. 2 Schematic representation of shallow aquifer recharge mechanism from SDWs

\section{Indigenous knowledge on exploration, digging and management of SDWs}

Following chronic shortage of water and harsh climatic conditions in Dodoma, local people have effectively learned key lessons and applied their IK in locating prime areas for SDWs development. Among the most widely used indigenous groundwater exploration methods include;

\section{The use of termites' mounds as indicator for groundwater/ high moisture}

The use of termites' mounds was one of the key IK groundwater exploration methods in Ntyuka, Ihumwa, Nzuguni,
Kitelela, Nzasa, Gawaye and, Mtumba suburbs of the municipality (Fig. 3). According to the locals in the aforelisted areas, the presence of termites' mounds is a direct indication of close WT as termites live closest to where they get water, especially during dry months. According to mama Pendo of Mtumba suburb; termites build mounds where there is shallow WT and, therefore, chances of finding shallow groundwater are higher on and/or close to the termites' mounds. "If you dig a well on a termite mound you are likely to get more water and at a much closer depth (WT). 'Most productive wells here in the village are dug on termite mounds and whoever SDWs away from the mounds ended up with dry wells or one with very little water and at much deeper depths" (personal communication with Mr. Jackson in Mtumba).

\section{Digging SDWs along faults and where older generations placed their wells}

Albeit locals would not call it a 'fault', the current field survey recorded many SDWs along clearly pronounced geological fault systems (Fig. 4).

According to the locals it is easy to dig wells where you already have 'natural caves on the rocks along a line' "faults", as the rocks would easily break along the natural fractures. The results show that several SDWs were found to be along continuous fault lines and were relatively more productive than wells away from the faults. As a results, many wells were developed in the faults to account for their relative high yield and the easiness to dig them. Most of such wells in Mtumba and Kisasa were almost continuously pumped and did not show any signs of decreasing yields. Interestingly, dowsing rods positively responded on top of fault wells to show presence of water in Mtumba, (Fig. 5).
Fig. 3 Showing a $103 \mathrm{~m}$ deep $\mathrm{BH}$ drilled close to a slightly weathered termite's mound, at Nzuguni, suburb. Notice that the $\mathrm{BH}$ is $\sim 1.5 \mathrm{~m}$ from the mound

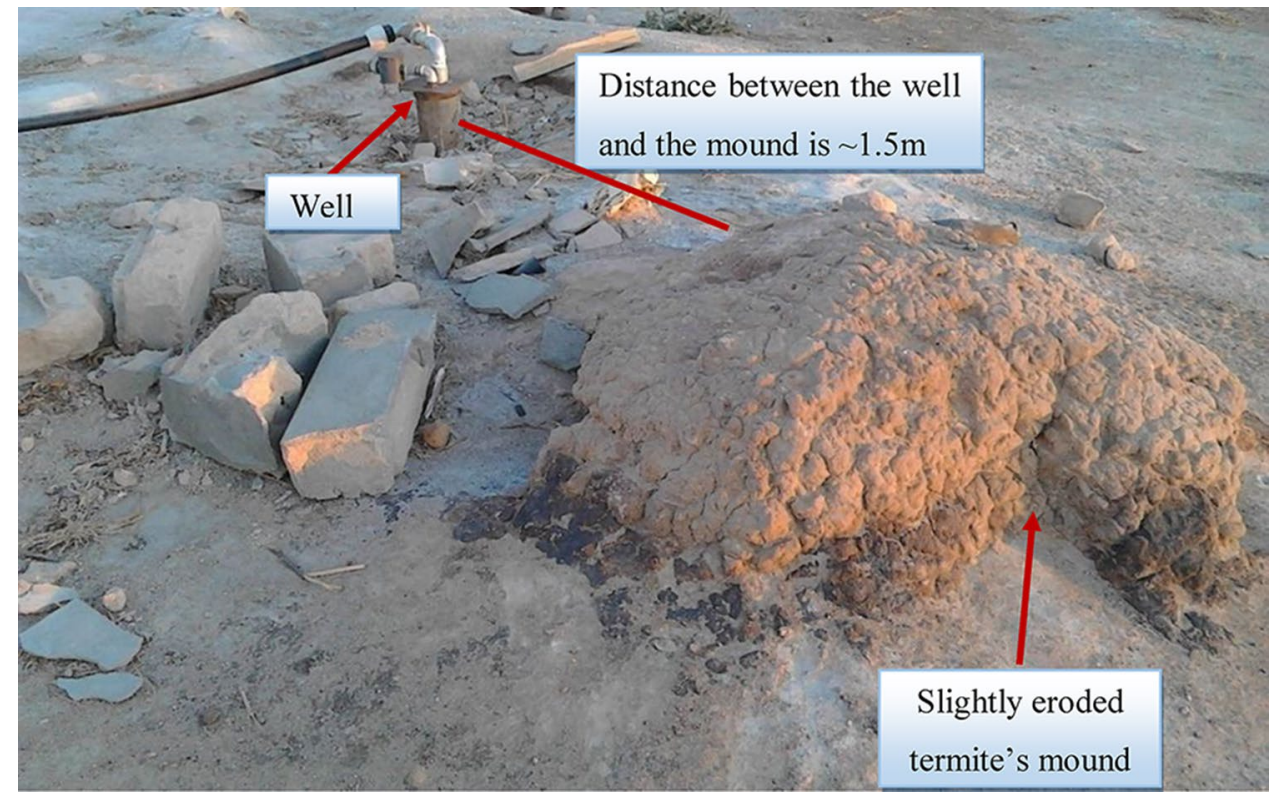




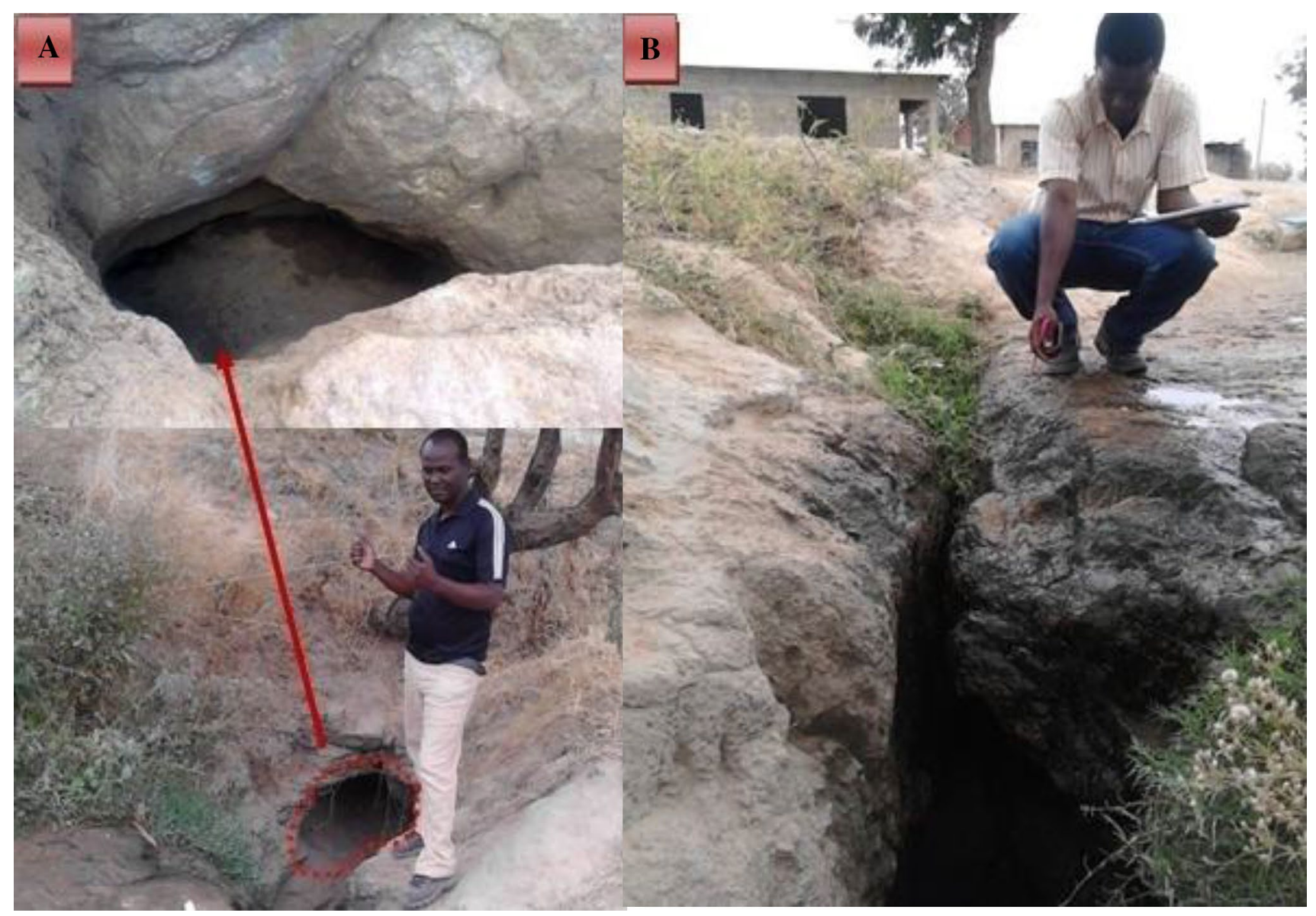

Fig. 4 Showing SDWs placed along natural fault systems. a Dowsing rods crossing on top of a SDW dug along a fault in Mahoma Makulu. b A very productive SDW along a fault system that is used for domestic and irrigation at Mtumba suburb. However, both wells are

(IK perfectly support simple modern groundwater exploration techniques).

Likewise, the results revealed that most wells, particularly those along faults occur where older generations placed their wells. "These wells have been here for many generations and we have only been doing minor maintenances such as removal of debris and weeding them", says Mama Adam of Mtumba suburb. She adds, 'If we are to dig new wells, we often dig them where the inherited wells are located. By so doing, we are connected to our ancestors and often get water'. Thus, local people have received/preserved knowledge from older generations about areas that were drilled many years ago. Focus group discussions in Mahoma Makulu revealed that locals mostly developed SDWs in the same localities as their older generations even if such locations do not have faults. Thus, the use of faults, valley bottoms and/or vegetation to indicate soil moisture seem to have been passed on from older generations and have successively helped the local people to be water sufficient (Personal communication with Mr. Mazengo, of Mtumba). vulnerable to pollution from runoff and periodical removal of debris is necessary. The SDWs in Mtumba are among the most productive in the area with an average yield of about $17 \mathrm{~m}^{3} / \mathrm{h}$ (Shemsanga et al. 2017)

\section{The use of vegetation as indicators for SGs (presence of moisture)}

The results further indicate that locals have a clear understanding of the relationship between presence of water and health of vegetation and would accordingly, dig their SDWs in such areas where the vegetation generally stayed greener and healthier than average. Thus, apart from digging SDWs during the peak of the dry season, when areas with healthier/ greener vegetation can only be because there is a source of water, locals also dig wells in areas where on average the vegetation remained greener for a longer period of time hence more likelihood of finding water. The greener the vegetation during the peak of a dry season the more the likelihood of finding groundwater (personal communication with Mr. Mabuya, a resident of Mtumba suburb). Likewise, FGDs with the local people indicated that certain trees species, mostly Ficus sycomorus, Acacia albida and, Adansonia digitata have the potential of inferring areas with high soil moisture contents. Such skills were mostly reported in

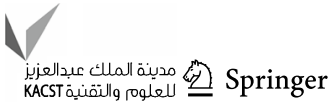




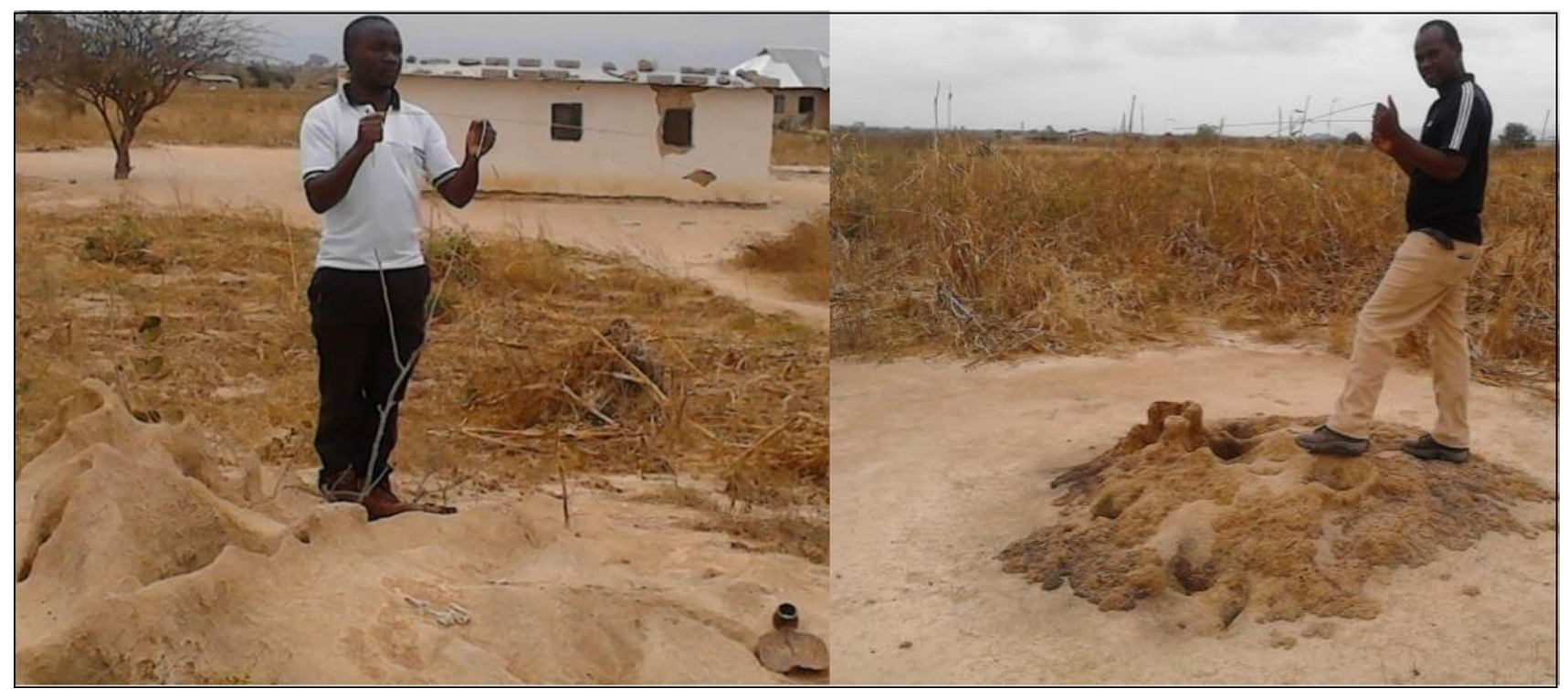

Fig. 5 Dowsing rods crossing on top of termite's mounds in Mtumba suburb indicating a closer water table, locals have trapped this technology to successfully explore and dig deeper SDWs

Mahoma Makulu, Gawaye, Msisi and, Mkondai suburbs. Indeed, several SDWs were placed along these trees and local people preserve the trees believing that they are themselves the sources of water (FGDS, FOs).

According to Mama Mahila and Mr. Mzanje, both residents of Mahoma Nyika, the moisture indicative species have widely been used to clue presence of water especially if investigations are done at the peak of the dry season. Elders in Mahoma Nyika and Mahoma Makulu, strongly linked the health of such vegetation at the peak of the dry season with higher proportions of soil moisture, which is strongly related to presence of a shallow WT. "Knowledgeable people within my village and even where i originate from explore for SDWs during the peak of the dry season and they would mostly dig SDWS where grasses and trees are greener at that season" says Mama Sechelela, a resident of Mahoma Makulu suburb.

Further, elders would observe certain cloud patterns, increased temperature and humidity as indicators of approaching rain events. For instance, by looking at certain flowering plants and trees and by sensing increased atmospheric humidity and temperature, older people in Mtumba, Nzuguni, Hombolo, Mahoma Nyika, Msalato, Veyula and, Zuzu, could forecast when the rains were approaching and accordingly prepare crop fields. This was observed at different times while the researcher was in the field where the elders would tell him that rainfall would pour soon, and it did. Moreover, elders often observe A. digitata and other plants in their communities such that when they put back their leaves after shedding them during dry season, it was an indication that the rain season was approaching. Similarly, certain flowering plants in the wetlands would start to bloom when the rains were approaching. In addition, they add that many other vegetation would look greener and start to produce new leaves and flowers just before the rains. These methods are widely applied in Dodoma and have helped locals to survive ages of water stress and food insecurity through well informed timing of timing of farming activities (FGDs).

\section{Geomorphology and river courses prospecting for likelihood of SGs}

Locals were also found to have some basic knowledge on the relationship between the likelihood of groundwater occurrence and geomorphological settings. Focus group discussions with locals in Ihumwa, Chololo and, Nzasa suburbs indicated the best localities to explore for water were on the valley bottoms where runoff often accumulates longer than the average areas and hence recharge the shallow aquifers. According to Mr. Mazengo of Chololo village, "it is not possible to get water on high raising landscapes as water flows towards the valleys". Furthermore, villagers suggest that areas where two or more rivers/streams intersect/meet have high potential for SDWs development.

According to the locals, moisture will accumulate in those areas for longer times and hence the corresponding SDWs are likely to last for longer periods during dry months. The fact that two water courses meet makes soil moisture stay for a longer time than the surrounding areas hence extended 
time for the water to infiltrate and recharge the aquifers (says Mr. Mazengo, Ihumwa).

Locals have capitalized on this hydrological fact and in many cases their wells were dug where river channels intersect. This was the case in Chololo, Mtumba and, Ihumwa suburbs where some wells were placed on and/or very close to seasonal river channels. The survey showed a series of such wells along water courses. Thus, locals have developed good skills in locating water along these water courses and FGDs showed that they prefer to dig wells in the aforementioned areas as they are most likely to get water for a longer period of time when other areas will have dried out.

\section{Indigenous knowledge on water quality, hardness and, seasonal water salinity}

Local people had a good understanding of the general water quality aspects, especially salinity, TH and seasonal variations in water salt contents. Furthermore, the survey revealed that; locals had some IK on catchment areas with relatively good quality water and/or where the water was salty, "bitter" as they would put it. According to elders in Hombolo for instance, wells developed on and/or close to a particular local valley, would most likely produce salty water and water which would not easily form foam with soap (FGDs). Apart from identifying salty wells and salty and/or hard water locations, elders in Mtumba and Mahoma Nyika were able to link concentration of water salinity with seasons. "During the peak of the dry seasons, the water becomes bitter and would progressively get better during rainy season, particularly during heavy rains years like 2007" (Personal communication with Mr. Mazengo of Mahoma Makulu suburb).

Further, immediately after digging SDWs and before the water is consumed by humans, locals in Chinangali, Nzasa and, Mpamaa suburbs would pour such water on the ground and let it dry out before it is categorised for use based on its quality. According to the locals, unfit water for humans, salty water and, water that would not easily form foam with soap (hard water) would normally leave white-chalky marks/ coloration on the ground and the respective SDWs would be designated as bad (having salt water) (FGDs and personal communication with Mama Mohamed Omar Sefu, a resident of Chinangali). While it is not possible to tell compositions of salts by this local skill, it still offers a general understanding of water with high salty contents which could be harmful to humans, livestock and, crops. This survey revealed that the water from wells that locals designated them as unfit had higher electrical conductivity (EC) of $>2500 \mu \mathrm{S} \mathrm{cm}-1$ following in situ testing. National and WHO water quality standards both shows continuous consumption of water with excessive salts and other chemical species is harmful (URT 2007; WHO 2008).
Further the survey revealed that, locals are already aware of potential health concerns from consuming poor quality water and some are already involved in disinfecting water for drinking by boiling, and/or sun sterilization in plastic bottles put on top of their premises roofs. For instance, in Mtumba suburb, isolated cases of disinfecting drinking water by putting water in plastic bottles and exposing them to solar illumination from roof tops were observed. Similarly, many families in Nzuguni, Mtumba and, Ihumwa reported that they were boiling their water to kill pathogens. Others bought special chemicals to put into their water for drinking to kill pathogens (FGDs).

\section{Important IK on SDWs management practices: prevention of erosion, encouraging recharge, identification of and, protection of recharge sites}

Generally, locals have some basic knowledge on identifying recharge sites where among most frequently identified areas were wetlands, flood plains along natural water courses. Focus group discussions showed that locals enhance recharge by protecting these recharge areas against adverse human activities such as farming and grazing. For instance, locals in Mahoma Nyika and Hombolo Makulu identified their local wetlands as directly recharging their aquifers and were actively educating each other on the need of protecting such areas for sustained life of the SDWs. In addition, locals in Mtumba, Ntyuka and, Nzuguni could clearly link runoff channels and rivers as potential recharge sites for their areas. Furthermore, locals could also link rainfall intensity, longevity and magnitude to groundwater recharge. For instance, residents of Mtumba linked years with poor rains with low water table and early drying up of the wells and accordingly would know which years they were likely to suffer from water shortage in their SDWs (drying SDWs).

The study found that SDWs in Veyula, Mtumba, Ihumwa, Nzuguni and, Mahoma Nyika have some structures that prevent them against siltation and drying up. For instance, certain portions of land around SDWs were left uncultivated so as to reduce direct erosion and SDWs siltation. Moreover, some plants are intentionally left to grow around the wells, mostly Cyperus rotundus, Acacia spp., among other. According to the locals, such vegetation generally stabilizes wells' edges and prevent siltation and wells collapsing. In addition, in Mtumba and Mahoma Makulu areas, pierces of land around the wells were left uncultivated to protect the wells from drying up, erosion, siltation and, wells' collapsing. "The land around my SDWs is well-vegetated with trees and grasses and no cultivation is performed on/near the wells so as to protect it from drying, siltation and erosion" (personal communication with Mr. Jackson of Mtumba suburb). 


\section{Water allocations, rationing and, separation of SDWs for various uses/users}

Locally, some villages had a well communicated arrangement regarding where humans and animals get their water. In many surveyed areas, certain wells are set aside for human and livestock uses. For instance, in Nzuguni, Mtumba, Ihumwa, Mahoma Nyika, Mahoma Makulu, Nzasa, Kitelela and, Mpamaa there were wells that humans collect domestic water and other wells are reserved for livestock. Local communication with the elders in those villages revealed that such arrangements were there since time in memorial and in many cases they inherited the wells for different uses from their older generations. According to the local people, sharing wells with livestock makes the water dirty and many times livestock destroy the wells hence forcing periodical maintenance. In a similar way, wells used for irrigation are also different from those used for domestic purposes. "To satisfy a large herd of livestock, one would need to abstract water several times from the wells, potentially steering sediments during the process', says Mzee Moses of Ihumwa suburb. This observation is contrary to wells abstracted for domestic uses only which are generally less frequented and hence the water generally remains clean (ones with less turbidity/suspended solids and matters). Likewise, wells used for irrigation are mostly different domestic wells which are often found within farms and near neighbourhoods, respectively.

\section{Discussions}

\section{SDWs density, their development and management practices}

The survey found that locals have useful skills in SDWs development and management. A total of 1248 SDWs were recorded in the field and these were mostly found in the outskirts of the city and poor neighbourhoods where no piped water connections exist (Table 1). These findings show that SDWs are heavily utilised by locals for nearly all water needs including domestic, bricks making, irrigation, livestock, construction and mixing of chemicals used against livestock and crop pests. To put the importance of SDWs into perspectives, average household income from vegetable and grapes gardens that are mostly irrigated with SDWs is $\sim 1700 \$=$ and $2600 \$$ per year. Numerous such gardens occur in the suburbs and are largely in response to booming vegetable market. Past studies showed SDWs were heavily used for irrigation (Baumann et al. 2005). These findings agree with past studies showing that between 20 and 30\% of Dodoma is suitable for SDWs development (Baumann et al. 2005). According to Baumann et al. (2005) suitability for SDWs development in the area is a function of its static water level (SWL) of at least $8 \mathrm{~m}$ or less. This is the exact situation in most areas of the municipality (Shemsanga et al. 2017).

The study revealed that there are specific individuals from the villages who are knowledgeable and have physical capacity to dig the SDWs. Such an individual would be paid an average of $150000 \mathrm{TSH}$ to dig a SDW that is about $15 \mathrm{~m}$ deep and having a surface dimension of $2 \times 3 \mathrm{~m}$. By the use of mostly traditional tools including a bucket and rope pulley system, such a well would be dug by an average of 3 people for between 45 and 60 days. These findings closely agree with past studies in Tanzania which concluded that it requires 2-7 weeks to dig a typical SDW depending on soil/ rock conditions, width, depth (Baumann et al. 2005).

Extreme cases were also observed where up to $45 \mathrm{~m}$ deep SDWs were dug in Mtumba suburb. Such wells were highly productive some of which sustained water needs for up to 120 families/households. The latter wells were also reported to offer reliable water supplies during dry season when average/shallower wells will have reduced yields and/or dried out (FGDs). These findings support common science that SDWs dry faster than deeper wells (Baumann et al. 2005). The findings show that SDWs are heavily utilised by the locals for nearly all water needs including cooking, laundry, washing, making bricks, irrigation, livestock, construction, cleaning human and livestock houses and, mixing of chemicals against livestock and crop pests and diseases (FGDs).

The current water supply infrastructures were first developed by colonial government in 1911 and mostly focused where the elites lived (Salama 1979). Back then, the population was small and groundwater, which is largely viewed as a common pool resource, was able to provide water sufficiency for all needs/people. During that time, however, locals were already able to get some water by digging their own SDWs and in the process accumulating and passing on key IK in developing and managing SAs. These IKs helped the locals to survive ages of water stress in such a climatically disadvantaged area. Albeit not documented, such skills are still being used today and are key to water sustenance for large populace that is still left by the piped water supply infrastructure of the municipality. These skills need to be well preserved now that there is a global vanishing of SDWs development and management skills (Kent et al. 2001).

Furthermore, the increased population and irrigation to meet growing markets mean that more SDWs are developed to counter balance the increased water demands. Within the study area, gardening has singly been recognised as demanding a lot of water, especially during dry months. Consequently, several SDWs have been opened in recent years to match increased vegetables demands (primarily due to the increased population brought by the recent relocation of 
central government to Dodoma) but also for neighbouring markets such as Dar-es-Salaam.

FGDs put average household's income from vegetables and grapes gardening that are mostly irrigated with SDWs at $\sim 1700$ and $2600 \$$ per year, respectively. This is regarded a good income locally and numerous such gardens occur in the suburbs, largely due to the booming vegetables and grapes markets. This will most likely continue to be the case as the current water development is biased towards urban centres and leave large part of the population in outskirts where huge amounts of water are needed with no reliable water supplies. Studies in Ethiopia showed that uncontrolled opening up of SDWs led to drying up of aquifer due to numerous SDWs dried up (Eregno 2007).

These findings contradict national statistics showing that up to $46 \%$ of rural Tanzanians use improved water (Baumann et al. 2005) and it is rightfully clear that national rural water supply and sanitation programme target of having $74 \%$ rural population with access to safe and improved water by 2015 would not be realized (Baumann et al. 2005). The latter development could be accounted by the fact that the city centre is relatively well connected to the formal water supply than the suburbs (URT 2003). However, these findings are in general agreement with the national statistics that show only $34 \%$ of the Tanzania population have access to piped water most of whom are in cities (URT 2002). Indeed, in many suburbs, no potable water connection exists and locals are entirely dependent on SDWs for all their water supply (FGDs, FOs). This, therefore, qualifies the shallow aquifer as an important water source and the need to be incorporated into the municipal water supply system. This also implies that SDWs need to be improved to realize their maximum potential for the people and to be incorporated into the overall integrated water resources management program. Globally, socio-economic context of many developing countries recognise SDWs as a key option for water supply where the other expensive technologies are often unavailable (De Louw et al. 2013).

Thus, the current increases in the number of SDWs in Dodoma is viewed as a necessity as many people do not have access to clean water including water for drinking. As a result, the SDWs are heavily used for daily water needs viz domestic, gardening, construction and livestock. The high dependence on the SDWs accounts to the fact that there is poor investment in water development and supply infrastructure which has resulted to only a small proportion of the inhabitants being connected to the piped water (URT 2003). Furthermore, many times the pipelines run dry leaving local people with no water supplies. Thus, high dependence on SDWs is largely considered as an adaptation to water stress and must be managed to prevent aquifer deterioration from over-exploitation especially because SAs are many times connected to the DAs (Shindo 1991; Pulido-Bosch et al.
2000; De Louw et al. 2013). However, it is worth noting that the country has signed and ratified several international legislations related to ensuring water sufficiency to her citizens it is expected that proper developments of water supply system be implemented (Nkonya 2011). This wider want can be simplified by systematic inclusions of IK skills on groundwater management which have enabled locals to survive generations of water stress. It is worth recalling that local people have ubiquitously dug wells since time in memorial which have supplied water long before the contemporary portability of water was invented (De Louw et al. 2013). Such people therefore must have accumulated important skills over the years which cannot simply be ignored. This is the exact situation in Dodoma Municipality but the rare skills remain untapped and clearly excluded from water governance, quite a predicament.

Thus, the IK on management of SDWs should be recognised as it is clear that shallow and deep aquifers are strongly interlinked (Shindo 1991). Further, the limited ability of the locals to dig deep wells means that the locals and the elites are exploiting different layers (shallow and deep aquifers, respectively) of the same interconnected resource. This makes it necessary for the managers to engage the locals in the holistic management of water resources. Clearly, the current uncontrolled digging up of numerous SDWs will not come without some costs, as past studies showed that areas most of SDWs developments are also hydrologically linked to the main aquifer supplying water in the city centre, the Makutupora basin which has already reported periods of decreased water levels (Rwebugisa 2008). Local groundwater also needs to be carefully managed as it is strongly influenced by rainfall that has shown a declining trend (Shemsanga et al. 2016).

\section{Drying up of SDWs and local response to current climate trends}

Although most SDWs have low yield, averaging at $1 \mathrm{~m}^{3} /$ day (CFR, 4.5.5), there has been some complaints that in recent years' the SDWs have showed decreasing water levels and yield and that about 13 such SDWs in Mahoma Makulu and Mahoma Nyika have completely gone dry except for runoff filling them during rains. Drying up of SDWs and low yields are partly the reason why more wells are being dug with the hope of finding more water particularly when such wells are needed for high water needs such as irrigation and livestock uses. In addition, FGDs with locals showed that several SDWs have become more ephemeral in recent years while they used to be perennial (Table 1). Focus group discussions further showed that owners of dried wells have either increased SDWs depths or dug new wells in prospectively better locations and with relatively deeper depths. Worth noting, during the peak of dry seasons, owners of ephemeral

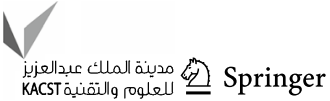


SDWs either opt to buy water from their neighbours and/or increase depths of their SDWs or dig deeper wells in prospective better locations. The latter developments have huge economic implications for the parties where a $20 \mathrm{~L}$ bucket of water is sold for between 50 and 100 Tsh. This explains why certain individuals have several wells some of which would become unproductive or with very low yields in the dry season.

Generally, water supplied from SDWs occurs in shallow water tables which are generally prone to climate variability and ET losses hence more sensitive to rapid WT fluctuations (De Louw et al. 2013). Likewise, there are multiple evidences of decreasing rainfall and warming trends in many semi-arid regions of Tanzania including Dodoma Municipality (Shemsanga et al. 2016, 2017). To support this argument, elders in Mtumba and Ntyuka villages clearly indicated that rainfall intensities, longevity and, magnitudes have all decreased in recent years which in turn have impacted yields in their SDWs as a direct result of altered recharge magnitudes and longevity (FGDs). Recent local climate studies recognize the direct role of rainfall on groundwater recharge (Taylor et al. 2012). Thus, the decreasing rainfall means less recharge and more temperatures mean higher PET, which again implies less capacity to recharge the SAs.

\section{Contribution of IK on groundwater management (enhancing recharge)}

Although, SDWs are mostly developed to abstract water from the SAs, the results show that they actually help to recharge groundwater by trapping water during storms and in the process offering increased time for deep percolation. This is especially vital because the local catchments have been altered by clearance of vegetation and are also compacted by human activities which often renders to more runoff and reduced infiltration (Valimba 2004). Thus, the more-or-less wide sizes of the SDWs locally (Fig. 1) means that significant volumes of water are trapped in them and left to infiltrate over an extended time. This is vital since local SDWs are often not fully utilized during rainy season as local dwellers would also use rain water for various uses. In the crop fields and even for domestic uses Thus, SDWs already act as recharge wells where there is a well-developed network of SDWs mostly close or along natural water courses. Generally, each time the 1248 SDWs are filled up during rains will potentially recharge $5.05 \mathrm{~mm}(\sim 1 \%)$ of the annual rainfall of about $550 \mathrm{~mm} /$ year compared to $\sim 5-10 \%$ that is naturally recharged through the vadose zone (Shindo 1991; Rwebugisa 2008). Thus, SDWs already work as AR wells that were planned in the areas to slow declining groundwater level but were never implemented due to resources restraints (Salama 1979). Potential SDWs recharge was also reported in Zanzibar where it was concluded that existing SDWs network could be improved by allowing rainwater to pass through filter media before allowed into the SDWs (RGZ 2007). Undeniably, the SDWs, which were originally meant to drain water from the aquifers, can also contribute to recharge process. Especially to be noted, many of these SDWs, particularly the ones used for irrigation, are not pumped during heavy rains as crops are naturally irrigated by rainfall and all water filling the wells will ideally recharge the SAs until when fully saturated. Thus, runoff is somewhat reduced and recharge fortified in such an area where the catchment has severely been adjusted by human.

Worth noting, SDWs recharge has been practised in more geologically challenging settings and have proved successful, sometime equalling natural recharge from rainfall (Sunderrajan et al. 2009). For instance, in India, it was found that more-or-less equal amount of recharge was happening from SDWs in the hard rock areas as the natural recharge mechanisms (Tularam and Krishna 2009). Local people in India recognize the roles of SDWs recharge during rainy season and the likelihood of getting more water in dry months (Sunderrajan et al. 2009; Anandaraja et al. 2008).

The challenge with this kind of artificial recharge (AR) locally is that most runoff comes with debris and have been noted to fill up the SDWs and clog fractures (Fig. 1). Large cross section area of the SDWs would also mean more ET during dry months (Fig. 1). Therefore, improved design of the SDWs and prevention of ET and direct runoff into the SDWs may improve water quality and the recharge process. However, there are still uncertainties that the individual SDW recharges may not necessarily benefit the owners in times of need during dry months. While this worry is valid, it is also true that recharge water used in any wells is a function of individual point recharges from the catchment and if many such schemes are made available and become well-coordinated, in the long run the catchments' WT will improve for all SDWs users. It is worth noting that the implementation of SDWs recharge in Dodoma Municipality would not be difficult as many SDWs already exist and local skills to develop new ones at low cost are available.

The challenge then remains on how to design SDWs that would not pollute groundwater from runoff contaminants which could range from nitrate to huge debris filling up the requiring periodical maintenances. In Kerala, India, SDWs recharge through freshwater from roof tops was attributed to improving water quality by reducing salinity and improve water table by up to $5 \mathrm{ft}$. (Raphael 2014). Thus, to control the problem of poor quality recharge water, attempts can be done to use roof top water to directly recharge aquifers via SDWs and completely prevent pollution. In addition, the same method was attributed to controlling the problem of high iron content in water. Within the study area, the problem of high salinity in SDWs water can also be controlled through this method. The success of the programme 
in Kerala led to successful replication of the procedure to other areas in India (Raphael 2014). These low-cost AR mechanism has a good chance of working as part of the infrastructure particularly SDWs and iron roofs already exist in the municipality. Similarly, small earthen dams, some of which already exists in the area, can be developed along chosen areas of SDWs to collect runoff and allow it to settle to separate sediments before allowing the water into the SDWs. This will help to store more water against high ET that often leads to most surface waters drying up a few weeks after rains (Shemsanga et al. 2016).

In India, progress has been made to develop national policy and strategy to encourage groundwater recharge from millions of such SDWs that were originally designed for irrigation but their potential for recharge ignored (Krishna et al. 2009). Locally, efforts can also be done to harness most recharge potential out of the SDWs by introducing better designs and improving well densities and depths especially along and/or close to the natural water courses (Fig. 2). These will technically play two folds' roles of providing water to the needy and enhance groundwater recharge process. Already, plenty of local skills are available, what is missing is coordination and provision of better designs and working tools. Indeed, the IK deserve better recognition, improvements and naturalisation into the overall water management plans and strategies as they already play vital roles in the overall water resources management while not officially recognised.

In areas of water stress, local people have developed IK in digging and managing SDWs (Chikodzi et al. 2014). Likewise, local people in Dodoma have well-developed IK on identifying, protection and, managing recharge areas and mechanisms. For instance, wetlands and rivers courses have repeatedly been identified as some of the most prominent recharge sites by the locals and have accordingly been protected against degradation and erosion. These efforts deserve better recognition, outscaling and above all, upscaling to other areas with similar environmental settings. It's worth noting that modern science also, recognizes the roles and potentials of wetlands and rivers as prolific recharge sources of many aquifers globally (Bergström 2013).

A series, other IK key for water resources management also exists globally where observation of insects and atmospheric phenomena such as halos have widely been used for weather forecasting long before the current meteorology was developed (Anandaraja et al. 2008). In India many locals are still without access to modern weather forecasting and the traditional weather forecasting which are centred at observation of the moon and insects play key roles in agricultural activities (Anandaraja et al. 2008; Sunderrajan et al. 2009). Further, in Kenya, farmers still prefer to combine modern and tradition weather forecasting methods which seem to work better there (Esipisu 2012). Unlike the situation in
India and Kenya, local people in Dodoma have immense knowledge at observing indicator vegetation and the changing of atmospheric humidity and timing of flowering plants and patterns to predict the approaching of rainfall seasons and would accordingly/timely prepare crop fields. In Zimbabwe, IK on groundwater management proved to be useful in monitoring and mapping groundwater fluctuations (Chikodzi et al. 2014). Such skills are often passed on through generations based on practical experiences and are useful to the populace in the absence of the modern technology and other resources constraints.

Furthermore, through the use of IK, scholars have discovered many important groundwater information that otherwise would not be possible. For instance, IK have been widely used to study groundwater management aspects, including in recent approaches such as groundwater modelling. With the help of IK and other information on water resources management from local people, Watts (2012) was able to successfully include past information into surface and groundwater models in Wudjuli Lagoon Australia. Similarly, the use of IK in groundwater modelling helped to properly monitoring water resources and allocations and ensuring that over-pumpage does not threaten local wetlands (Watts 2012). It is, therefore, inappropriate to ignore such vital efforts in water resources management as local people have been developing and managing water resources particularly SDWs and the general SAs for centuries from which strong skills have been gathered, accumulated and, passed on through generations (McDonald et al. 2005).

\section{Insignificant recognition of contribution of SDWs and IK in water supply}

Although $20-30 \%$ of the study area is suitable for development of improved SDWs (Baumann et al. 2005), officially there is no emphasis on SDWs as a possible source of water supply in Dodoma city. Personal communication with leaders of WRB puts it clear that SDWs are currently not part of current water supply plans in the city. "One cannot plan to include SDWs in the formal water supply systems of Dodoma as it is difficult to rely on them" (personal communication with Mr. Mihale, WRB). While this position may be right, it is also arguably true that SDWs already support many people in the suburbs, piped water supply in Dodoma is not reliable and only a few people are connected (URT 2003). However, SDWs have major advantages over boreholes that are worth considering in the overall water resources of Dodoma and beyond. Unlike for boreholes, the level of local involvement is already high, highly skilled labour is often not required, SDWs are most of the time affordable to locals, the wells serve as own reservoirs and often no storage tanks are needed, SDWs are often developed where water is needed and, therefore, no heavy 
infrastructural costs to lay pipe lines are necessary and cheap technology is often/readily available (Shamsudduha 2009). Further, the fairly large storage capacity from the relative large sizes/widths of SDWs offer a possibility of producing sufficient water even when aquifer permeability is low and all materials needed to dig typical SDWs are readily available. Likewise, if operational pumps are installed, water can still be abstracted at times of pump faults, through a bucket and pulley system, which are not uncommon in many developing countries. In addition, horizontal drilling often done in SDWs can improve water yield and finally, SDWs maintenance can be done by the readily available skills at a local level compared boreholes (De Louw et al. 2013). One can, therefore, argue that these traits qualify SDWs as important water sources for the poor and that they cannot simply be ignored.

The fact that local people (mostly poor) and the elites in the city centre get their water supplies from different layers of the same interconnected aquifer (shallow and deep aquifers, respectively) necessitates managers to integrate the local peoples' efforts and their IK in the overall water management plans. Locally, however, SDWs have several management problems requiring improvements to prevent polluting the aquifers both shallow and deep and over-abstraction of the groundwater for the whole agrarian society. Similarly, frequent drowning of humans and livestock into poorly developed SDWs and excessive water loses via the semi-arid ET would need to be addressed. Simple technologies that are locally available and affordable such as fencing the wells with readily available materials, and putting SDWs covers/ lids would completely remove the problem.

These findings clearly show that the current water management settings have major disjoints between the much advocated national water policy that focuses on integrated approaches and what is actually been practised in the city. Yet, the rick IK, that are vital in the local groundwater management aspects, are not clearly echoed in the basin authority management plans/strategies. However, SAs and Das are often closely interconnected, contamination and/ or over-abstraction of the shallow aquifers would inevitably impact closely intertwined deep aquifers (Shemsanga et al. 2017). Thus, the broad management of the local water resources requires IK to be preserved and incorporated in the official groundwater management plans. Furthermore, there is a sharp contrast to the national water policy that primarily intends to manage water resources (surface and groundwater, shallow and deep aquifers) holistically. The findings agree with the national statistics that shows that about $30 \%$ of rural water supply infrastructures are not working well and/ or poorly managed (URT 2002). These findings also contradict the core values of the much advocated IWRM nationally, which by the virtue of its, definition should involve all players, much so the local people and their rich IK on water resources governance (URT 2002, 2009).

Further, irrespective of the recognition of the vital roles of IK on management of natural resources, education and, knowledge sharing by the UN (ISDR 2012), little is being done locally to link the roles of IK with groundwater management. Thus, the importance of IK information management and exchange is not implemented locally. Likewise, the UN guidelines requiring the use of relevant traditional values to be shared with all interested and affected parties and adapted to different target audiences for the common benefits of all players is not applied. It is the view of this study that, although not recognized, IK already play a big role in ensuring water sufficiency to the riparian society something that was to be done by the government. Thus, inclusion and adapting some of the good IK is the way forward and so is improving the technically bad practices locally. Therefore, acknowledging, understanding and, respecting IK must be done to succeed in the much advocated national water policy and IWRM (URT 2010). Globally, integration of IK in management of natural resources have provided better acceptance and results than centrally i.e. planned top-bottom programmes (Hoppers 2002; Hoppers 2002; Nyong et al. 2007).

\section{Vegetation as indicator of shallow groundwater/ aquifers}

Observation of vegetation as an indicator of groundwater is widely practised locally (FOs and FGDs). For instance, areas where the vegetation is greener and healthier than average areas at the peak of dry seasons are often suspected of having closer water table. Thus, locals would dig SDWs in such areas and often locate water (FOs, FGDs). Interestingly, the practice of using the status of the vegetation health as an indicator of groundwater and/or soil moisture is constant with modern science (Mata-González et al. 2012; Nocco et al. 2013; Sommer and Froend 2014). Locals in ancient times also used vegetation and soil moisture as indicators of groundwater (Kent 2001). Recent studies recognize the role of vegetation health as an indicator of soil moisture (Dorigo et al. 2012; Ridler et al. 2012). Thus, local people have repository of skills that are important tools for water resources management in the area and beyond and must be conserved and most importantly improved, included in the water resources management strategies.

In contrast, certain plant species are associated with close water table and wherever they are spotted, locals would dig wells around those areas. One such tree that has repeatedly been identified by local people was Ficus sycomorus, among others that could not be identified in the field. The truth of the matter, however, is that the naturally/preferred ecological range of Ficus sycomorus is water logged localities (Galil and Eisikowitch 1968). In 
EA, the tree prefers river banks where moisture is plenty year-round (Ibid). Thus, the fact that $F$. sycomorus grows in the suspected groundwater potential areas is simply because the ecological niche of tree requires presence of a lot water to flourish and locals in Dodoma use this fact to successfully explore for SDWs. Clearly, such efforts cannot simply remain untapped in the current water policy framework.

The results further show that locals have basic knowledge of trees which consume more water. For instance, locals in Mtumba mostly plant indigenous tree like Acacia spp. trees and singled out Eucalyptus spp. trees as consuming more water and, therefore, should not be planted near recharge areas and SDWs. Interestingly, Eucalyptus spp. are considered among heavy water consumers and scholars equally discourage planting them in water sensitive and stressed areas (Kaburi and Medley 2011; Menge 2013). Thus, locals have a good understanding of environmental conservation and it is plausible to integrate such skills in the overall management of groundwater. Thus, such skills should be well documented for effective management of groundwater locally and beyond as they support environmental awareness and conservation.

\section{Prospecting for SDWs using geomorphology and surface hydrology}

Generally, locals had high skills on groundwater flow patterns and dynamics including linking geomorphology and groundwater occurrence and flow. Close observation of many local SDWs reveals that apart from wells being placed on geological faults, termites' mounds and, water indicator plants, most other wells were sited along rivers/runoff channels, valley bottoms and, wetlands. In many cases, geophysical surveys have located wells in more-or-less similar localities to where local peoples' wells exist (Personal communication with Mrs. Mcharo, WRD, Dodoma, and FOs). Indeed, most productive wells in Dodoma, including those from the main well field, MWF, are placed on wetlands, flood plains and, along drainage channels (Shindo 1991, FOs). However, it is a common understanding that groundwater flow closely follows general geomorphology and most notably surface water flow (Shindo 1991; Nag and Ghosh 2013). Worth noting, natural water channels and wetlands are prime recharge areas (Stellato and Newman 2013). This is very useful as such localities would often get recharge from the rains and also benefit from the seasonal rivers. Thus, these seasonal rivers and wetlands provide more recharge time than the mere rains, which often end up as runoff due to high rates of catchment modification and compaction by removal of vegetation and human activities (Shemsanga et al. 2017).

\section{Co-existence of termites' mounds and groundwater}

One groundwater exploration technique that was used in nearly all surveyed areas includes the use of termite's mounds as indicator of shallow groundwater. Locals strongly associate the mounds with good chances of locating groundwater at closer depths. However, the relationship between termites' mounds and high soil moisture is scientifically well accepted. Ecologically, termites require presence of close water table water for their survival during dry seasons (Crook et al. 2013). Thus, it has been proved scientifically that presence of termites' mounds indicates high soil moisture and locals in Dodoma have capitalised on this fact (Crook et al. 2013). Interestingly, groundwater explorers from MASOCHI Water Resources Exploration Co. Ltd, Dodoma, often use termites' mounds as a starting point for geophysical surveys (FOs). By coincidence, modern groundwater geophysical survey in Nzuguni found the best borehole location only about $1.5 \mathrm{~m}$ from a termites' mound (Fig. 3). Two more deep wells were placed on top of termite mounds in Zuzu and Chololo suburbs (File observation). Thus, this IK seems to work well in Dodoma and has helped locals to locate highly productive wells that remained perennial throughout the year (FGDs). Similarly, simple groundwater exploration technique using dowsing rods, that helps locals to locate best SDWs locations, strongly deflect and cross on top of termite mounds as compared to adjacent areas (filed measurements and observations, Fig. 5). Interestingly, some SDWs diggers in Mtumba periodically used dowsing rods to locate most suitable areas for SDWs development (FGDs). In other areas, it was observed that people that are commercially engaged in the digging SDWs increasingly use dowsing rods to ensure their digging is successful. This shows that mixing of traditional groundwater exploration skills like the use of termite mounds and simple groundwater explorations like dowsing rods can enhance water availability and that locals can receive new technologies and the modern skills can be disseminated to them. The dowsing rods were particular used in areas already suspected to have water and more-or-less served as confirmation steps before digging (Personal communication with Mr. Charles Jackson, a local SDWs digger). Thus, with proper inclusion of the locals, modern groundwater development skills can effectively be disseminated to them and ensure water sufficiency to a larger part of the city. This suggest that the local IK have some scientific backings and, therefore, cannot simply be ignored like in the status quo. Improved designs are thus likely to be received as locals already understand the challenges and any better ways of carrying the assignment is likely to be accepted. Thus, the use of termite mounds to locate wells can be extended to similar regions with shortage of water such as 
Singida and Tabora. Thus, groundwater managers should consider at local people as partners and co-manage the aquifers and not otherwise.

\section{Occurrence of groundwater along geological faults}

This study revealed that local people in Dodoma have placed their SDWs along geological faults for a long time (FOs and FGDs). Further, it was found that the locals inherited the indigenous exploration technique from their older generations in which many wells were placed along, what they called, mapango 'earth caves'. Interestingly, it is scientifically accepted that assessment of structures and patterns of faults is vital for groundwater exploration. According to Elder Mcharo, a senior hydrogeologist at the WRD Dodoma, local faults are among the most viable localities for groundwater exploration. In addition, the most productive wells at Makutupora depression are all placed along geological faults particularly Mlemu and Kitope faults (Shindo 1991; Rwebugisa 2008). Generally, the likelihood of groundwater occurrence along faults is a well-known science (Zhang et al. 2014) especially when the faults intersect the ground surface (Siebert et al. 2007). Locally, several wells along faults had high yields (FOs and measurements). Two SDWs in Mtumba had tested yield of about $17 \mathrm{~m}^{3} / \mathrm{h}$ in the peak of dry season and were heavily utilized for domestic and gardening and did not show signs of reduced yield after $3 \mathrm{~h}$ of continuous pumpage (field measurements). Generally, wells along faults sustain important livelihood systems locally where they often serve as the only source of water in many areas (Fig. 1). However, if water is required at the appropriate quality, the SDWs along such faults must be protected against runoff from manure, foot paths, roads, livestock sheds/houses and, pit latrines wastes all of which have the potential of polluting SDWs (FOs). Figure 5 shows that runoff from the aforementioned sources can easily access the wells with the potential of contaminating the wells/aquifers.

\section{Water quality and seasonal variation in salinity and water disinfection}

The results show that locals have good skills on water quality, hardness and, suitability aspects and accordingly designate various SDWs for different uses based on their specific water quality. The survey revealed that areas known to have blackish and fresh water are purposefully dug for livestock and domestic water supplies, respectively. Generally, wells with salty waters were carefully identified by locals and accordingly used for the purposes that would suit the comparatively high salinity contents. In most cases, such waters were reserved for irrigation, livestock and, brick making as opposed to domestic use. In other villages, however, water from all SDWs were generally salty in which case, users were left with no choices between different sectors. This was mostly observed in Kitelela suburb where locals were forced to walk long distances to collect fresher water from neighbouring areas and/or opted to fetch water from comparably less salty wells (FGDs). Worth noting, interviews held in Ihumwa and Mahoma Makulu were able to show where to dig SDWs with relatively good and salty quality water. Interestingly, one particular location of the catchment was pointed as having salt water and indeed field measurements of its quality recorded high EC of $\sim 4500$. These skills are considered crucial now when there are increasing scramble for freshwater resources and when poor water quality is of global concern (Olokesusi 2004; Biswas 2008).

In addition, locals recognise seasonal variations in salinity and were able to show that it was higher during the peak of dry season and progressively reduced in rain months (FGDs). Locals, however, were unable to explain why there were such seasonal variations in salt content of the SDWs. The locals failed to link seasonal salt dilution due to recharge and subsequent concentrations with ET and over-abstraction during dry months, and the fact that at the peak of dry seasons, recharged water would have interacted with the soil/ rock matrices for a longer period (Elisante and Muzuka 2015). Generally, the seasonal salinity variation as observed by the locals would be affected by the direct recharge into the aquifers/wells during wet season (De Louw et al. 2013; Shemsanga et al. 2017). In addition, chances of water from the wells mixing with runoff water are also likely to be another factor in regulating saltiness during rainy season (Fig. 1). In contrast, since the wells are shallow and mostly open to ET, pure water from SDWs progressively escape the mixture and in the process leaving more salt concentrated waters. Furthermore, during the dry season, the water being abstracted is pure groundwater that has interacted with salt minerals in the rock matrix for relatively longer periods (Elisante and Muzuka 2015). Similarly, since the wells are shallow and mostly open to ET, pure water progressively escape the mixture and in the process leaving more salt concentrated waters. In contrast, rainfall renewals would see mostly rainfall water recharging the wells hence diluting it. However, since the SDWs are mainly recharged by local rains as opposed to deep aquifers which are thought to benefit from regional contributions, the decreasing rainfall trends (Shemsanga et al. 2016, 2017) would directly affect shallow aquifers the most.

In addition, some areas of Mtumba and Nzuguni, local people allow runoff to pour into the wells to reduce the high water salinity. While this may help to temporarily reduce the salts, it poses imminent danger to clog wells' fractures, fill up the wells volumes, polluting the wells and, potentially the aquifer from runoff contaminants such as manure and effluents from shallow pit latrines which are not uncommon in the area (Fig. 1). It would be interesting to ascertain 
how dilution of water by direct runoff mean in terms of SAs pollution by analysing key water quality parameters such as nitrate and faecal matters. A study in Arusha found that wells that were open to runoff were more polluted than those prevented from direct runoff and which were recharged by water that had filtered through the soil matrix (vadose zone) (Elisante and Muzuka 2015). Previous studies indicated that nitrate pollution was a major problem in groundwater (Nkotagu 1996b, c; Shemsanga et al. 2017). Equally important and as a response to water related ill health, locals in Mtumba treat water for drinking from SDWs by solar disinfecting them using plastic bottles. Treatment of water for drinking in plastic bottles is a good sanitation practice that has proved success globally and would need to be upscaled and outscaled. Locally, solar disinfection should be effective and cost effective methods as will utilize high local solar UV potential and if well-planned is likely to work better. Solar disinfection of drinking water is also advocated by present hygiene practices worldwide and has proved to be effective in controlling water borne diseases including cholera particularly in Africa (Conroy et al. 2001; McGuigan et al. 2012).

\section{Water allocation, rationing and separation of wells for different uses/users}

Rationing, prioritization and, timing water uses and allocation plans are vital water management aspects that are widely applied by the local people in Dodoma Municipality. The current results reveal that there were wells that are set aside for humans and some for others uses such as livestock, irrigation and, bricks making. The sorting of SDWs for various uses is primarily a function of its quality, particularly salt contents and water hardness i.e. easiness to form foam with soap. Generally, humans had the first priority ahead of livestock, construction, brick making and, irrigation. In Hombolo Makulu and Ihumwa centres for example, humans' wells were well-protected and their water looked clean compared to wells used by livestock. In the aforementioned locations, the wells used by humans had low EC values of $<1000$ compared to those used for other purposes which had much higher values (Field measurements). Interestingly, in places where wells were shared by humans and livestock, timing of water uses was imposed where morning hours were mostly reserved for humans whilst later hours were for livestock and gardening. In Mayamaya, domestic water would be fetched from 5:00 to 10:00 am (when livestock would be grazing and later visit the wells from 3:00 pm onwards). The rest of the day would be spent by humans. However, locals often failed to associate the fact that, apart from the water looking dirty or clean, livestock wastes often increase the chances of nitrate pollution. Elisante and Muzuka (2015) and URT (2002b) showed that livestock were among the leading causes of SGs pollution.

In addition, even when separated, wells used by humans and livestock were often very close to each other, in some cases $<10 \mathrm{~m}$. This close proximity of the wells used by humans and livestock may as well lead to cross contamination. Furthermore, in Nzuguni and Nzasa suburbs, livestock wells were found to be upstream of humans wells which leaves a possibility of the livestock polluted water to flow and reach human wells. Previous studies showed that most wells had serious nitrate pollution of up to $450 \mathrm{mg} / \mathrm{L}$ (Nkotagu 1996b, c). It would be expected for example to have human wells in the upstream of the catchment and the livestock wells on the downstream. This is one area that researchers could improve management of groundwater, particularly SAs and SDWs.

Generally, the aforementioned local groundwater allocation skills seem to work well as animals would normally be grazing in the pasture lands in the mornings and would stop by to drink as they are trailed back to their sheds/closets/bomas in the evenings. Nevertheless, the challenge with this method is that although the water would look clearer in the morning, it would not guarantee that the water is safe from contaminants such as nitrate which is locally associated with livestock wastes. Past studies revealed that high nitrate in groundwater was linked to poor sanitation and livestock wastes (Nkotagu 1996b). It should be mentioned that high nitrate in water is dangerous as it leads to Blue Baby Syndrome to young livestock and humans (Shaheen 2015; Shemsanga et al. 2017). The best case scenario would be to avoid taking animals in the well fields as they would inevitably drop a lot of nitrate in the process. The way forward may be to carry water to some locations away from the well fields and where runoff would not go back to the wells and the catchment. Yet, to control pollution and high nitrate rates, the entire agrarian catchment may need to be re-looked at as opposed to point wells/sources (Nkotagu 1996b; Rwebugisa 2008).

\section{Conclusions and recommendations}

Owing to sustained water stress coupled with harsh climatic conditions and poor investment in water supplies in Dodoma Municipality, SDWs remains vital sources of freshwater for the populace. In this study, a total of 1248 SDWs were surveyed mostly in the city's suburbs where they were often the only sources of freshwater supplies. Thus, the chronic water stress in the municipality has triggered local people to develop and pass on vital IK on both SDWs developments and management. Clearly, the local IK framework on development and management of SG provides for water sufficiency to large part of the city's population that is not 
currently connected to piped water supplies. The key local IK includes explorations of groundwater via the use of termites' mounds and vegetation as indicators of presence of groundwater, digging SDWs along geological faults, identifications of wetland and natural water courses as sources of recharge and accordingly protecting them, among many others. Thus, while the scientific route to manage groundwater is hampered by many challenges including data and resources constraints, with minimal improvements, and proper recognition of local IK can contribute to effective groundwater management framework via aforementioned IK. This highlights recent developments in inclusive water governance, such as socio-hydrology, where interplays between hydrological and social processes including co-evolutions and self-organisation of humans-water systems using different cultures and skills are considered vital and must be integrated. Thus, the interplay between the local IK and water resources in Dodoma Municipality offers such a success story which deserves to be better recognised, upscaled and, outscaled to other areas with comparable hydrological and socio-economical settings. However, the aforementioned remain clearly undocumented and missing in the local water governance strategies and policy interpretations.

Further, the well-developed water allocation plans between different users and uses work fine locally and with little conflicts. Generally, some SDWs are often set aside for livestock and others for humans' uses. Clearly, locals have a good understanding of water quality issues, especially on salinity and potential for water pollution from livestock. For instance, different wells are dug in different areas to suit different uses based on their salinity content and pollution potential. In addition, water that is considered polluted is often left for livestock and/or irrigation purposes. Likewise, there were areas that were clearly identified as having high saline contents and polluted waters. However, there are still challenges to do with specific aspects of groundwater pollution between humans and livestock wells that seems to be missing in the current local structure. For instance, the issue of cross contamination between humans and livestock sells seems not to be considered by local people. This is the area where efforts can be pulled to improve the existing structure by provision of specific instructions to the fairly recipient local society.

Further, locals have vital skills on the roles of different components of the water cycle including on recharge zones. Already locals protect areas they consider to be recharge zones and patches of land around SDWs are often left uncalculated to prevent erosion, reduce debris from entering the wells and, collapsing of the SDWs structures/surfaces. The aforementioned are all key environmental conservation aspects worth preserving. Yet, they remain clearly undocumented in the existing water governance efforts which undermines sustainable water management.
Further, the IK already helps the recharge process where up to $1 \%$ of the local rainfall recharges the SAs through SDWs. Thus, water managers should especially include locals and their rich IK to design better wells that would provide for water sufficiency but at the same time promote recharge mechanisms. Irrespective of these rich IK, however, the local SDWs are not currently recognised as key water supply systems in the existing water programmes, which undermines their adaptations and management. However, such skills are worth included in the contemporary groundwater management measures as local SDWs already play vital roles in water supply for various social-economic activities, including agriculture and domestic uses. Thus, it should be stressed that IK and modern science can coexist and make, management of groundwater in Dodoma city practical and ensuring more people are water sufficient but in a sustainable way.

Acknowledgements The funding was provided by the Government of Tanzania.

Open Access This article is distributed under the terms of the Creative Commons Attribution 4.0 International License (http://creativeco mmons.org/licenses/by/4.0/), which permits unrestricted use, distribution, and reproduction in any medium, provided you give appropriate credit to the original author(s) and the source, provide a link to the Creative Commons license, and indicate if changes were made.

\section{References}

Anandaraja N, Rathakrishnan T, Ramasubramanian M, Saravanan P, Suganthi NS (2008) Indigenous weather and forecast practices of Coimbatore district farmers of Tamil Nadu. Indian J Tradit Knowl 3(7):630-633

Baumann E, Ball P, Been A (2005) Rationalization of drilling operations in Tanzania. Review of the Borehole Drilling Sector in Tanzania. Working paper

Biswas AK (2008) Integrated water resources management: is it working? Water Resour Dev 24(1):5-22

Chen Z, Grabby SE, Osadetz KG (2004) Relation between climate variability and groundwater levels in the upper carbonate aquifer, southern Manitoba, Canada. J Hydrol 290(1):43-62

Chikodzi, D., Murwendo T, Simba FM (2014). Reliability of indigenous knowledge in monitoring and mapping groundwater fluctuations in Zimbabwe. Working paper

Conroy RM, Meegan ME, Joyce T, McGuigan K, Barnes J (2001) Solar disinfection of drinking water protects against cholera in children under 6 years of age. Arch Dis Child 5(4):293-295

Crook D, Tripathi S, Jones R (2013) The sustainability of Suranga irrigation in South Karnataka and Northern Kerala, India, 1st World Irrigation Forum

De Louw P, Eeman S, Oude Essink G, Vermue E, Post V (2013) Rainwater lens dynamics and mixing between infiltrating rainwater and upward saline groundwater seepage beneath a tile-drained agricultural field. J Hydrol 501:133-145

Dorigo W, Jeu R, Chung D, Parinussa R, Liu Y, Wagner W, Fernández-Prieto D (2012) Evaluating global trends (1988-2010) in 
harmonized multi-satellite surface soil moisture. Geophys Res Lett 39(18):1-7

Elisante EM, Muzuka ANN (2015) Occurrence of nitrate in Tanzanian groundwater aquifers: a review. Appl Water Sci 7(1):71-87

Galil J, Eisikowitch D (1968) On the pollination ecology of Ficus sycomorus in East Africa. Ecology 49:259-269

Hammouri N, El-Naqa A, Barakat M, (2012) An integrated approach to groundwater exploration using RS and GIS. J Water Resour Prot 4(9):153-172

Hardjoamidjojo S, Pramudya B, Murtilaksono K (2007) Performance of Shallow Groundwater Irrigation Schemes in Nganjuk-East Java, Indonesia

Hoppers OC (2002) Indigenous knowledge and the integration of knowledge systems. Towards Philos Articulat 2-22

ISDR UN (2012). Hyogo framework for action 2005-2015: Building the resilience of nations and communities to disasters. Extract from the final report of the world conference on disaster reduction (A/CONF. 206/6), 16 March 2005

Job CA (2010) Groundwater economics. Cambridge University Press, Cambridge

Kaburi SM, Medley KE (2011) Community perspectives on fuelwood resources in East Africa: enrichment and extraction along the eastern slopes of Mount Kenya. Mount Res Dev 31(4):315-324

Kashaigili J (2010) Assessment of groundwater availability and its current and potential use and Impacts in Tanzania. Report prepared for the International Water Management Institute. Sokoine University of Agriculture, Morogoro, Tanzania

Kent M, Owen NW, Dale P, Newnham RM, Giles TM (2001) Studies of vegetation burial: a focus for biogeography and biogeomorphology? Prog Phys Geogr 25(4):455-482

MacDonald AM, Calow RC, MacDonald DM, Darling WG, Dochartaigh BE (2009) What impact will climate change have on rural groundwater supplies in Africa? Hydrol Sci J 54(4):690-703

MacDonald A, Dochartaigh O, Bonsor B, Davies HJ, Key R, (2010) Developing quantitative aquifer maps for Africa. Working paper

Manap MA., Nampak H, Pradhan B, Lee S, Sulaiman WNA, Ramli MF (2014) Application of probabilistic-based frequency ratio model in groundwater potential mapping using remote sensing and GIS. Arab J Geosci 7(2):711-724

Mata-González R, McLendon T, Martin D, Trlica M, Pearce R (2012) Vegetation as affected by groundwater depth and microtopography in a shallow aquifer area of the Great Basin. Ecohydrology 5(1):54-63

McDonald E, Coldrick B, Villiers L (2005) Study of groundwaterrelated Aboriginal cultural values on the Gnangara Mound, Western Australia. Working paper

McGuigan KG, Conroy RM, Mosler HJ, du Preez M, Ubomba-Jaswa E, Fernandez-Ibañez P (2012) Solar water disinfection (SODIS): a review from bench-top to roof-top. J Hazard Mater 235:29-46

Menge SN (2013) The role of communication in environmental management and conservation in Kenya: a case study of Nyanturago water catchment Kisii County, Nairobi Univer. Working paper

Mjemah IC, Van Camp M, Walraevens K (2009) Groundwater exploitation and hydraulic parameter estimation for a Quaternary aquifer in Dar-es-Salaam Tanzania. J Afr Earth Sci 55(3):134-146

Mjemah IC, Van Camp M, Martens K, Walraevens K (2011) Groundwater exploitation and recharge rate estimation of a quaternary sand aquifer in Dar-es-Salaam area, Tanzania. Environl Earth Sci 63(3):559-569

Muchingami I, Hlatywayo D, Nel J, Chuma C (2012) Electrical resistivity survey for groundwater investigations and shallow subsurface evaluation of the basaltic-greenstone formation of the urban Bulawayo aquifer. Phys Chem Earth 50:44-51

Nag S, Ghosh P (2013) Delineation of groundwater potential zone in Chhatna Block, Bankura District, West Bengal, India using remote sensing and GIS techniques. Environ Earth Sci 70(5):2115-2127
Nkonya LK (2011) Realizing human right to water in Tanzania. Hum Rights Brief 17(3):5

Nkotagu H (1996a) Origins of high nitrate in groundwater in Tanzania. J Afr Earth Sci 22(4):471-478

Nkotagu H (1996b) Application of envirironmental isotopes to groundwater recharge in a semi-arid fractured crystalline basement area of Dodoma, Tanzania. J Afr Earth Sci 22: 443-457

Nkotagu H (1996c) The groundwater geochemistry in a semi-arid, fractured crystalline basement area of Dodoma, Tanzania. J Afr Earth Sci 23(4):593-605

Nocco M, Kucharik C, Kraft G (2013) Evaluating regional water scarcity: Irrigated crop Water budgets for groundwater management in the Wisconsin Central Sands, AGU Fall Meeting Report

Nyong A, Adesina F, Elasha BO (2007) The value of indigenous knowledge in climate change mitigation and adaptation strategies in the African Sahel. Glob Change 12(5):787-797

Olokesusi F (2004) A Survey of Indigenous Water Management and Coping Mechanisms in Africa: Implications for knowledge and Technology Policy, ATPS/EIIPD Conference on Science, Technology Water and Environment in Africa. Addis Ababa, Ethiopia

Pritchard M, Mkandawire T, O'neill J (2008) Assessment of groundwater quality in shallow wells of southern districts of Malawi. Phys Chem Earth. 33(8):812-823

Pulido-Bosch A, Bensi S, Molina L, Vallejos A, Calaforra J, PulidoLeboeuf P (2000) Nitrates as indicators of aquifer interconnection. Application to the Campo de Dalías (SE-Spain). Environ Geol 39(7):791-799

Raphael JC (2014) Ground Water cum "Dug Well” Recharge of Coastal Eco Systems: Recharging with Roof Rainwater supports desalination of Coastal Water Bodies: The Case of Kerala, India

Ridler ME, Sandholt I, Butts M, Lerer S, Mougin E, Timouk F, Kergoat L, Madsen H (2012) Calibrating a soil-vegetation-atmosphere transfer model with remote sensing estimates of surface temperature and soil surface moisture in a semiarid environment. J Hydrol 436:1-12

Rwebugisa RA (2008) Groundwater Recharge Assessment in the Makutupora Basin, Dodoma, Tanzania, M.Sc. Thesis. International Institute for Geo-Information Science and Earth Observation, Enschede

Salama RB (1979) Dodoma capital city water resources study. Government printers, Dodoma, Tanzania. Unpublished Government Report

Shaheen G (2015) Factory farming: a cruel practice. AYER 3:91-99

Siebert C, Rödiger T, Mallast U, Gräbe A, Guttman J, Laronne JB, Storz-Peretz Y, Solomon S (2007) Climate change - The physical science basis: Working group I contribution to the 4th assessment report of the IPCC, vol 4. Cambridge University Press

Shemsanga C, Muzuka ANN, Martz L, Komakech H, Omambia AN (2016) Statistics in climate variability, dry spells, and implications for local livelihoods in semiarid regions of Tanzania: the way forward. In: Chen W-Y, Seiner J, Suzuki T, Lackner M (eds) Handbook of climate change mitigation and adaptation. Springer Science and Business Media, New York

Shemsanga C, Muzuka ANN, Martz L, Komakech HC, Elisante E, Kisaka M, Ntuza C (2017) Origin and mechanisms of high salinity in Hombolo Dam and groundwater in Dodoma Municipality Tanzania, revealed. Appl Water Sci 7:1-23

Shindo S (1990) Study on the recharge mechanism and development of groundwater in the inland area of Tanzania. Report of the Japanese-Tanzanian Research Mission. Chiba University

Shindo S (1991) Study on Recharge Mechanisms and Development of Groundwater in Inland Areas of Tanzania. Japanese-Tanzanian Research Mission Report. Chiba University

Sommer B, Froend R (2014) Phreatophytic vegetation responses to groundwater depth in a drying Mediterranean-type landscape. J Veg Sci 25(4):1045-1055

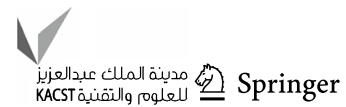


Stellato L, Newman B (2013) Groundwater inputs to rivers: hydrological, biogeochemical and, ecological effects inferred by environmental isotopes. Assessing nutrient dynamics in River basins 187

Sunderrajan K, Rajnarayan I, Shah T, Hittalamani C, Patwari B, Sharma D, Chauhan L, Kher V, Raj H, Mahida U, Shankar M (2009). Is It possible to revive dug wells in hard-rock India through recharge? Discussion from studies in ten districts of the country, Strategic Analyses of the National River Linking Project of India Series 5. Proceedings of the Second National Workshop on Strategic issues in Indian Irrigation. IWMI, p 197

Tularam GA, Krishna M (2009) Long-term consequences of groundwater pumping in Australia: A review of impacts around the globe. J Appl Sci Environ Sanitation 4(2):151-166

Taylor RG, Koussis AD, Tindimugaya C (2009) Groundwater and climate in Africa-a review. Hydrol Sci J 54(4):655-664

Taylor RG, Todd MC, Kongola L, Maurice L, Nahozya E, Sanga H, MacDonald AM (2012) Evidence of the dependence of groundwater resources on extreme rainfall in East Africa. Nat Clim Change 3:374-378

Troch P (2000) Data assimilation for regional water balance studies in arid and semi-arid areas (Case study of Volta basin upstream of Akosombo dam, Ghana), Workshop report 163

URT (United Republic of Tanzania) (2002) National Water Policy (NAWAPO). Ministry of Water and Irrigation, Dar-es-SalaamTanzania. Government Printers Dar-es-Salaam
URT (United Republic of Tanzania) (2003) Population projection, water demands and, sewerage generation estimates. Water Supply and Sewerage Improvements in Dodoma. Unpublished Government Report. Ministry of Water and Livestock Development

URT (United Republic of Tanzania) (2009) Water Resources Management Act of 2009. Government Printers, Dar-es-Salaam

URT (United Republic of Tanzania) (2010) Water. United Republic of Tanzania

Wurzel P (2001) Drilling boreholes for hand pumps. Desktop Publishing: Erich Baumann, SKAT, 2 (Working paper on water supplies and environmental sanitation)

Zealand SN (2011) Water Physical Stock Account: 1995-2010. Statistics New Zealand, Wellington

Zhang R, Jiang Z, Zhou H, Yang C, Xiao S (2014) Groundwater outbursts from faults above a confined aquifer in the coal mining. Nat Hazards 71(3):1861-1872

Publisher's Note Springer Nature remains neutral with regard to jurisdictional claims in published maps and institutional affiliations. 